\title{
Identification of a conditionally essential heat shock protein in Escherichia coli
}

\author{
Leonard F. Peruski Jr. *, Frederick C. Neidhardt \\ Department of Microbiology and Immunology, University of Michigan Medical School, Ann Arbor, MI 48109-0620, USA
}

Received 28 February 1994

\begin{abstract}
Protein D48.5 was recognized as a heat-inducible protein of Escherichia coli during the screening of a group of random, temperature-inducible Mud-Lac fusion mutants. Physiological and genetic analysis demonstrated that (i) the structural gene for this protein, designated $h t p I$, is a member of the $\sigma^{32}$-dependent heat shock regulon, (ii) at $37^{\circ} \mathrm{C}$ the synthesis of protein D48.5 is nearly constitutive, increasing slightly with growth rate in media of different composition, and (iii) this protein is essential for growth at high temperature.
\end{abstract}

Key words: Heat shock; Two-dimensional gel electrophoresis; Heat shock protein; Regulon; (E. coli)

\section{Introduction}

Escherichia coli undergoes a rapid and dramatic change in its pattern of protein synthesis in response to a shift to high temperature [1]. This change involves the induction of many proteins, some of which are the members of the $\sigma^{32}$-dependent heat shock response regulon [2]. More recently a second heat shock regulon has been discovered, with the transcription of its members under the positive control of a newly identified alternative sigma factor, $\sigma^{24}$ $[3,4]$. Currently only two genes are known to be regulated by $\sigma^{24}: r p o H$, which encodes $\sigma^{32}$, and htrA which encodes an endopeptidase [3-6]. In contrast, the $\sigma^{32}$-dependent heat shock response involves about 20 polypeptides that are coordinately and transiently induced upon a shift up in temperature. A peak rate of synthesis of these proteins is reached between three and eight minutes postshift, with the rate of synthesis declining to a new steadystate rate greater than the pre-shift temperature. The induction upon a shift to $42^{\circ} \mathrm{C}$ differs in magnitude among the proteins, ranging from 5- to 20 -fold greater than the preshift rate $[2,7,8]$. Studies from several laboratories have shown that the heat shock genes of $E$. coli comprise a

\footnotetext{
* Corresponding author. Present address: National Center for Human Genome Research, National Institutes of Health, 4815 Topping Road, Rockville, MD 20852, USA. E-mail: lenperuski@aol.com.
}

regulon, sharing a common positive regulatory protein, $\sigma^{32}$, (the $r p o H$ gene product or HtpR), an alternative sigma factor for core RNA polymerase [4,9,10]. Evidence both in vivo and in vitro indicates that the level of $\sigma^{32}$ present in the cell can determine the activity of heat-shock genes, and that at least one component of the induction process is an elevated level of $\sigma^{32}$. This elevation in the level of $\sigma^{32}$ can be brought about in several ways. In the case of a temperature shift the $\sigma^{32}$ level can be elevated by the increased transcription of $r p o H$ or increased translation of existing $r p o H$ mRNA. In the case of infection by lambda virus, the level is increased by a reduction in the proteolytic degradation of $\sigma^{32}[4,9,11-14]$.

In contrast to good understanding of the role of $\sigma^{32}$ in mediating the heat shock response, it is still unclear what the induction of these heat-shock proteins accomplishes and why no cell has succeeded in eliminating this response from its regulatory network. The heat shock response has been implicated in several apparent cellular roles: removal of denatured proteins, protection or repair of DNA, maintenance of membrane function, and the coordination of cell cycle processes $[2,11,15,16]$. However, until more of the heat shock proteins can be assigned precise activities and related to cellular processes, the complete understanding of the role of the response in cellular physiology will remain a mystery. Less than half of the $\sigma^{32}$-controlled heat shock proteins have been characterized biochemically and genetically [2]. Here we report the discovery and the preliminary 
analysis of a new heat shock protein, protein D48.5, the product of the $h t p I$ gene. This gene is under the transcriptional control of $\sigma^{32}$, and can be activated by increasing the cellular level of this factor. At $37^{\circ} \mathrm{C}$ protein $\mathrm{D} 48.5$ is made constitutively at a rate that increases slightly with growth rate. Curiously, protein D48.5 is essential for growth, but only at elevated temperature.

\section{Materials and methods}

\subsection{Bacterial strains, transposons, and plasmids}

Various E. coli $\mathrm{K}-12$ strains, plasmids, and transposable elements were used for the physiological and genetic studies. These strains and vectors are described in Table 1.

\subsection{Media and growth conditions}

Cells were grown aerobically at selected temperatures in rotary-action water baths with growth monitored spectrophotometrically at an optical density of $420 \mathrm{~nm}$. Temperature shifts were done by transferring small volumes of cultures between adjacent, prewarmed water baths. Several types of media were used during the course of this study. The defined minimal and rich media have been previously described [17]. Complex, natural product media used included Luria broth, trypticase soy broth (Difco), and MacConkey's agar (Difco). Luria Broth was made as described by Maniatis et al. [18]; the remainder were prepared according to the manufacturer's directions. Where necessary, agar (Difco) was added to a concentration of $1.5 \%(\mathrm{w} / \mathrm{v})$ to make solid media. The $\beta$-galactosidase indicator, 5bromo-4-chloro-indolyl $\beta$-D-galactoside (X-gal), was used at $15 \mu \mathrm{g} / \mathrm{ml}$ in some of the plate media. Lactose phenotypes were tested on X-gal and MacConkey plates.

\subsection{Radioactive labeling and $\beta$-galactosidase assays}

Induction ratios, cellular levels, and rates of synthesis were determined as previously described $[1,7,19]$. For visual inspection of proteins, cultures $(1.0 \mathrm{ml})$ were labeled with $\left[{ }^{35} \mathrm{~S}\right]$ methionine $(1.25 \mathrm{mCi} / \mathrm{mmol} ; 50 \mathrm{mCi} / \mathrm{ml})$ for a 15-minute period prior to temperature shifts, and chased with $0.167 \mathrm{ml}$ of $0.2 \mathrm{M}$ methionine for $5 \mathrm{~min}$. A portion (1 $\mathrm{ml}$ ) of the shifted cultures was labeled in a similar fashion from three to eight minutes after the temperature shift and then chased for three minutes. These samples were resolved by two-dimensional gel electrophoresis, and autoradiograms made. The level of $\beta$-galactosidase was assayed as described by Miller [20]. The relative rates of synthesis of $\beta$-galactosidase were calculated by the method of Yano et. al [14].

\subsection{Two-dimensional gel electrophoresis and genetics}

Whole cell extracts were made by sonication and their proteins resolved by two-dimensional gel electrophoresis [22-24]. Finished gels were dried and exposed to film either by autoradiography or fluorography, depending on the isotope label. Tetracycline sensitive strains were made using the protocol of Maloy and Nunn [21]. Matings were performed as described in Miller [20]. Transformations were done as described in Maniatis et al. [18].

\section{Results}

\subsection{Discovery of a heat-shock protein and its lacZ fusion}

Fourteen independent Mud-Lac fusion strains that displayed a temperature-inducible Lac phenotype were examined by two-dimensional gel electrophoresis of $\left[{ }^{35} \mathrm{~S}\right]$ methionine labeled extracts made before and after a shift

Table 1

Bacterial strains and plasmids

\begin{tabular}{|c|c|c|}
\hline \multicolumn{3}{|c|}{ A. Bacterial strains and genotypes } \\
\hline CAG5051 & $\left(\mathrm{HfrH} 96^{\prime} \leftarrow 17^{\prime}\right)$ nadA ::Tn10 thi-1 relA spoT supQ80G & CAG \\
\hline K165 & $l a c_{a m} \operatorname{trp}_{a m}$ pho am $\sup C_{t s}$ strA mal mam $r p o H_{a m}$ & $\mathrm{SC}$ \\
\hline K166(pFN97) & Isogenic with K165, except recA. pFN97 is $r p o H^{+}, \mathrm{Amp}^{\mathrm{R}}$ & \\
\hline K2357 & SlacU169 proC ${ }^{+}:: \operatorname{Tn} 10\left(\right.$ tet $\left.^{\mathrm{R}}\right)$ his ilv gale 490 chlD-blu $\Delta 8 \Delta$ bam nutL 44 cI857 $\Delta H I$ & DIF \\
\hline K2357-9 & Isogenic with $\mathrm{K} 2357$, except $h t p I:: l a c Z, \mathrm{Amp}^{\mathrm{R}}, \mathrm{Cam}^{\mathrm{R}}$. Created by mu $\mathrm{dX}$ insertion & DIF \\
\hline K2357-91 & Same as $\mathrm{K} 2357-9$, except Tet ${ }^{\mathrm{S}}$ & \\
\hline $\mathrm{K} 2357-92$ & $\mathrm{~K} 2357-91 \times \mathrm{CAG} 5051$ & \\
\hline $\mathrm{SC} 122$ & Parent of K165. Isogenic with K165, except $r p o H^{+}$ & $\mathrm{SC}$ \\
\hline W3110 & $F^{-} \lambda^{-}$Wild type & \\
\hline \multicolumn{3}{|c|}{ B. Plasmids and transposons } \\
\hline mu dX & Bacteriophage mud-lac transposon, $\mathrm{Amp}^{\mathrm{R}}, \mathrm{Cam}^{\mathrm{R}}$, lacZ & $\mathrm{CAG}$ \\
\hline pDS2 & EcoRV clone of a ptac::rpoH fusion. Amp ${ }^{\mathrm{R}}$ & DS \\
\hline
\end{tabular}

Sources of strains, transposons, and plasmids are as follows: BW = Barry Wanner, Purdue University; CAG $=$ Carol A. Gross, University of Wisconsin at Madison; DIF = David I. Friedman, University of Michigan; DS = David Strauss, University of Wisconsin at Madison; SC $=$ Stephen Cooper, University of Michigan. 
up in temperature from 28 to $42^{\circ} \mathrm{C}$. Ten of the isolates showed no detectable changes in the pattern of protein synthesis. Four of the isolates were shown to be missing a common polypeptide spot, designated protein D48.5 Protein D48.5 has an apparent molecular weight of 48500 and a $\mathrm{p} I$ of 5.1. Fig. 1 shows the Lac phenotype of the parental strain, K2357 and one of its Lac fusion derivatives, K2357-9 ( $h t p I:: l a c Z$ ), on MacConkey plates after overnight incubation at 28 and $42^{\circ} \mathrm{C}$ (panels $\mathrm{A}$ and $\mathrm{B}$ ). In panels $\mathrm{C}$ and $\mathrm{D}$ comparable sections of autoradiograms of the parental strain, K2357, and one of its fusion derivatives, K2357-9 ( $h$ tpI::lacZ), labeled following a shift from 28 to $42^{\circ} \mathrm{C}$. Protein D48.5 is induced upon a heat shock in the parent, K2357, while in K2357-9, the polypeptide spot is missing, presumably as a result of the mu $\mathrm{dX}$ [25] insertion into htpI.

\subsection{Heat shock synthesis of protein D48.5 and its gene fusion requires $\sigma^{32}$}

To determine whether protein D48.5 was a heat-shock protein, it had to be shown that it was heat inducible and under the control of $\sigma^{32}$. As a first step in this proof, $E$. coli $\mathrm{K} 12$ strains $\mathrm{SC} 122\left(\mathrm{rpoH}^{+}\right), \mathrm{K} 165$ ( $r p o H 165$ ), and $\mathrm{K} 166$, a recA derivative of strain $\mathrm{K} 165$ containing a plasmid, pFN97 $\left(\mathrm{rpoH}^{+}\right)$, were grown at $28^{\circ} \mathrm{C}$ in rich Mops medium and shifted to $42^{\circ} \mathrm{C}$. Portions of the cultures

\section{A. MacConkey, $28^{\circ} \mathrm{C}$ K2357 (htplt)}

\section{K2357-9 (htpl::lacZ)}

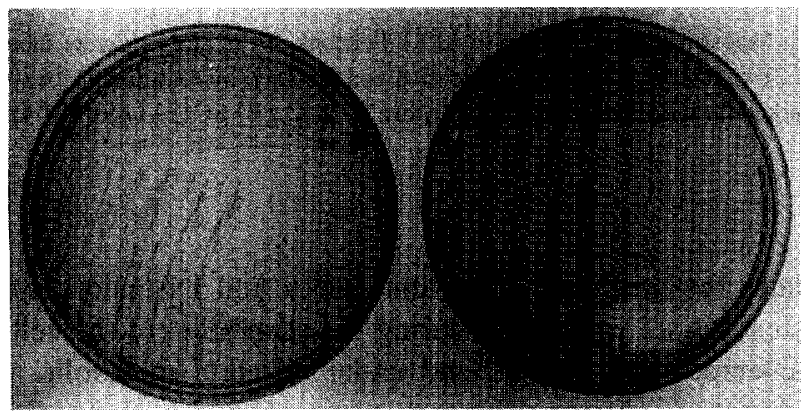

\section{C. $\mathrm{K} 2357$ (htpl+)}

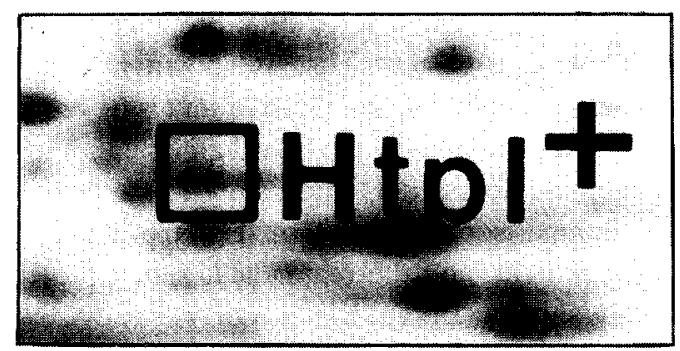

were labeled with $\left[{ }^{35} \mathrm{~S}\right]$ methionine for $5 \mathrm{~min}$ at $28^{\circ} \mathrm{C}$ and from 3-to- $8 \mathrm{~min}$ after the shift to $42^{\circ} \mathrm{C}$. Samples were analyzed by two-dimensional gel electrophoresis and are shown in Fig. 2. Panel A shows the basal level of protein D48.5 in strain SC122 grown under steady-state conditions at $28^{\circ} \mathrm{C}$. As shown in panels $\mathrm{B}$ and $\mathrm{D}$, only in strains $\mathrm{SC} 122$ and $\mathrm{K} 166$ is the synthesis of protein D48.5 induced upon a temperature shift from 28 to $42^{\circ} \mathrm{C}$. In strain K165 there is no detectable induction of protein D48.5 after the same temperature shift (panel C). While these autoradiograms suggest that protein D48.5 is under the control of $\sigma^{32}$, further analysis of the effect of $\sigma^{32}$ on the expression of htpI and its fusion were done as described below.

The data in Fig. 3 shows the induction ratio for strains SC122 and K165 grown under the same conditions as described above. Protein D48.5 exhibits an induction ratio of 5.7 in strain SC122 and little or no induction in strain $\mathrm{K} 165$ (rpoH165). The time-course of the induction of protein D48.5 shown in Fig. 3 is typical of most E. coli heat shock proteins [16].

Hyperproduction of $\sigma^{32}$ results in the induction of most of the proteins of the heat shock response, including protein D48.5 [25]. To verify that the heat shock expression of the htpI::lacZ fusion was under the control of $\sigma^{32}$, a plasmid, designated pDS2, carrying $r p o H$ linked to the IPTG inducible promoter, tac, was transformed into the $h t p I$ fusion strain, K2357-9. An $\mathrm{F}^{\prime}$ containing the lacI $_{q}$

\section{B. MacConkey, $42^{\circ} \mathrm{C}$} K2357 (htpl+) K2357-9 (htpl::lacZ)

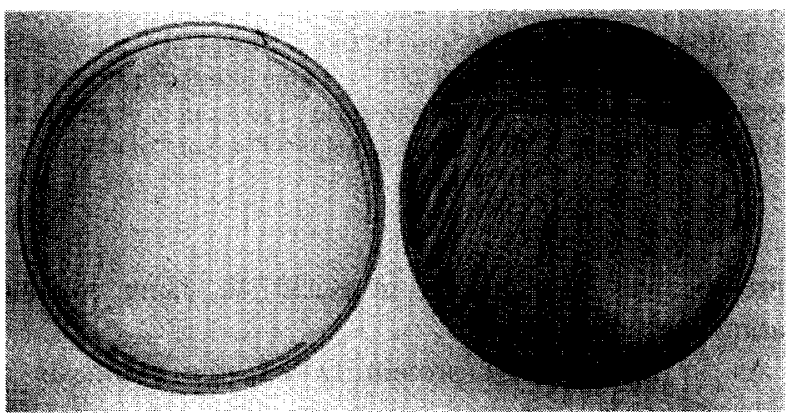

\section{K2357-9 (htpl::lacZ)}

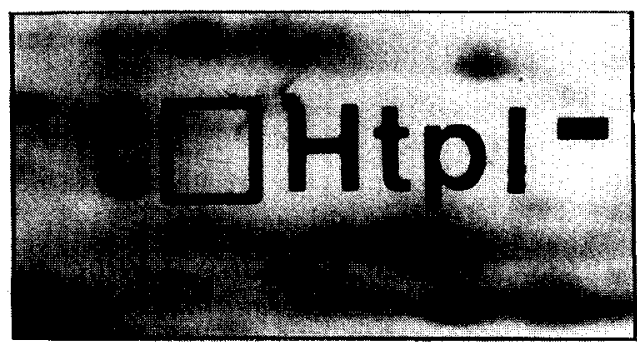

Fig. 1. Discovery of protein D48.5 and a LacZ fusion in its gene. Using the bacteriophage transposon, Mu dX, a transcriptional fusion of the protein D48.5 gene to $l a c Z$ was created. $E$. coli strain $\mathrm{K} 2357$ was infected with $\mathrm{Mu} \mathrm{dX}$ ( lac $^{+} \mathrm{Amp}^{\mathrm{R}} \mathrm{Cam}^{\mathrm{R}}$ ) and screened for LacZ phenotype at 28 and $42^{\circ} \mathrm{C}(\mathrm{A}, \mathrm{B})$. Several isolates that displayed a temperature inducible $\mathrm{Lac}^{+}$phenotype were examined by two-dimensional gel electrophoresis (C, D). The position of protein D48.5 is indicated on the autoradiograms. (The fusion strain, K2357-9, was constructed by Linda Eades and Alan Schauer of this department.) 

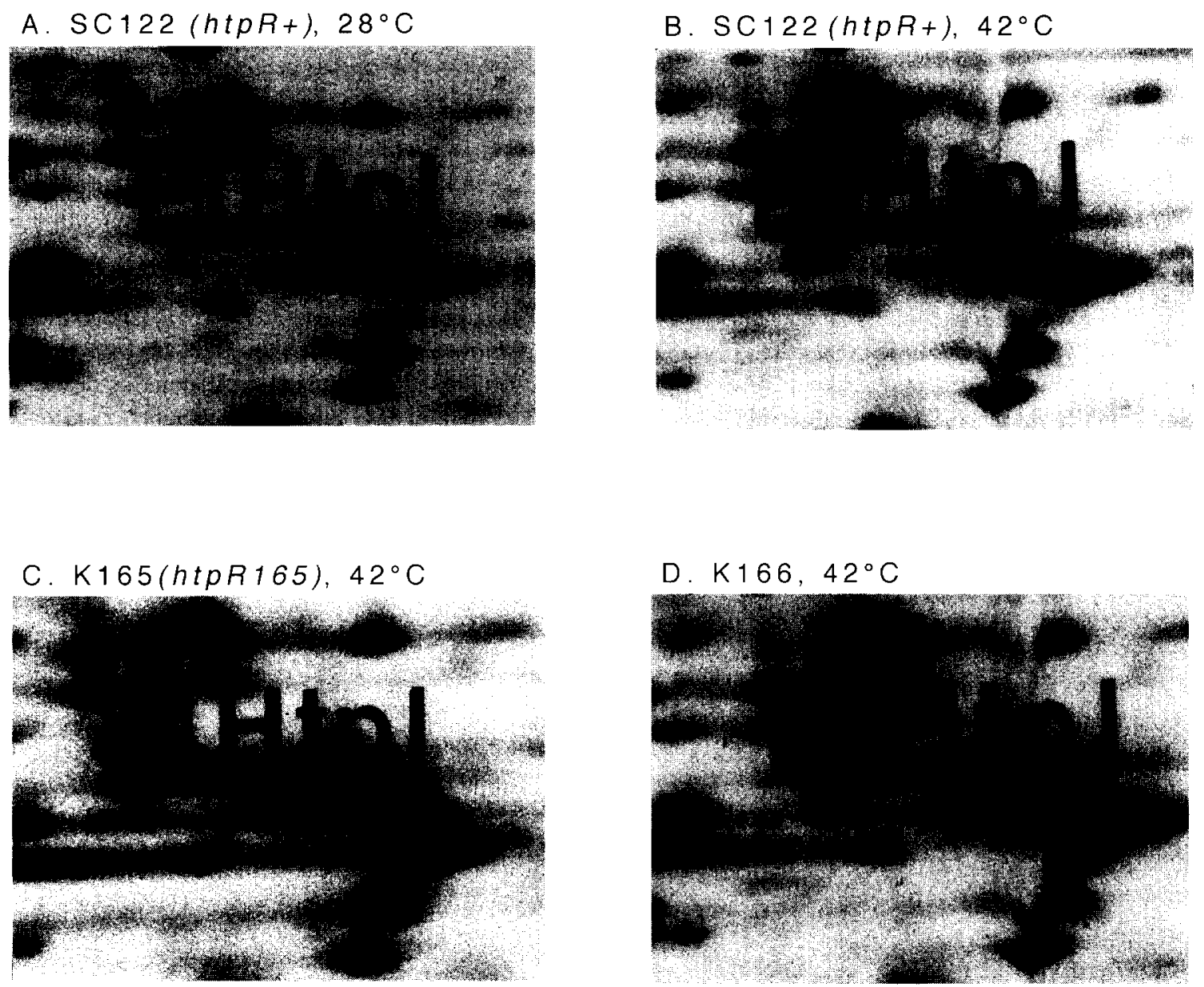

Fig. 2. Heat shock induction of protein D48.5. Strains were grown at $28^{\circ} \mathrm{C}$ in rich Mops media and shifted to $42^{\circ} \mathrm{C}$. Portions of the cultures were labeled with $\left.{ }^{35} \mathrm{~S}\right]$ methionine for $5 \mathrm{~min}$ at $28^{\circ} \mathrm{C}$ and from 3-to-8 min after the shift to $42^{\circ} \mathrm{C}$. Extracts were made by sonication and resolved by two-dimensional gel electrophoresis, followed by autoradiography. The location of protein $\mathrm{D} 48.5$ is marked on the films. (A) $\mathrm{SC} 122\left(r p o H^{+}\right) 28^{\circ} \mathrm{C},(\mathrm{B}) \mathrm{SC} 122\left(r p o H^{+}\right) 42^{\circ} \mathrm{C}$, (C) $\mathrm{K} 165$ (rpoH165) $42^{\circ} \mathrm{C}$, and (D) $\mathrm{K} 166\left[\mathrm{pFN} 97\left(r p o H^{+}\right)\right] 42^{\circ} \mathrm{C}$.

repressor was also placed in $\mathrm{K} 2357-9$, using standard mating procedures [20].

As in the case of protein D48.5, the synthesis of $\beta$-galactosidase increased when the level of $\sigma^{32}$ was increased by the addition of IPTG. In the fusion strain K2357-9 the level of $\beta$-galactosidase activity was 72 units without IPTG while in strain K2357-9(pDS2) the level was 75 units. When assayed for $\beta$-galactosidase activity $15 \mathrm{~min}$ after the addition of IPTG to a final concentration of 5 $\mathrm{mM}$, the levels of activity were 70 and 268 units, respectively. The level of $\beta$-galactosidase made as a result of the hyperproduction of $\sigma^{32}$ is similar to the level of protein D48.5 made under the same conditions [16].

\subsection{Physiological analysis of htpI and the htpI::lacZ fusion}

Having established that protein D48.5 was a product of the heat shock regulon, we examined how the cell regu- lates the synthesis of protein D48.5 and its fusion under steady-state conditions, during the adaptation of the cell to a temperature upshift, and under different metabolic and growth conditions. This was accomplished both by direct measurements on protein D48.5 resolved on two-dimensional gels and by measuring the expression of the reporter gene, lac $Z$, in the fusion.

A plot of both the relative level of protein D48.5 and the fusion-expressed $\beta$-galactosidase is shown in Fig. 4. Under steady-state conditions, the relative levels of protein D48.5 and $\beta$-galactosidase are in close agreement, showing a steady increase across the temperature range from 28 to $46^{\circ} \mathrm{C}$. For comparison, the relative levels of Ef-Tu, a non-heat shock protein, and the major heat shock protein, DnaK are also shown. Ef-Tu has a fairly steady level across the temperature range examined, while proteins of the heat shock regulon display a profile similar to that of DnaK and protein D48.5, with levels that increase rapidly with temperature. 
The manner in which the steady state level of a protein varies as a function of growth rate can in some instances provide a clue to its metabolic function [24]. The effect of different metabolic conditions on the steady-state synthesis of protein D48.5 was tested by examining autoradiograms of strain W3110 that had been grown under steady-state conditions at $37^{\circ} \mathrm{C}$ on four Mops-based media designed to give a range of growth rates [24]. The results of this survey are summarized in Fig. 5. Protein D48.5 behaves as a Ic protein [24], having a steady-state level that increases as the growth rate increases.

Many polypeptides undergo dramatic changes in their relative differential rates of synthesis following temperature shifts. The relative differential rates of synthesis for both protein D48.5 and fusion expressed $\beta$-galactosidase are shown in Fig. 6. Both protein D48.5 and fusion expressed $\beta$-galactosidase display a dramatic change in relative rates of synthesis following a shift up in temperature. The differential rate of synthesis increases nearly 4-fold after a shift to $42^{\circ} \mathrm{C}$ and nearly 5 -fold after a shift to

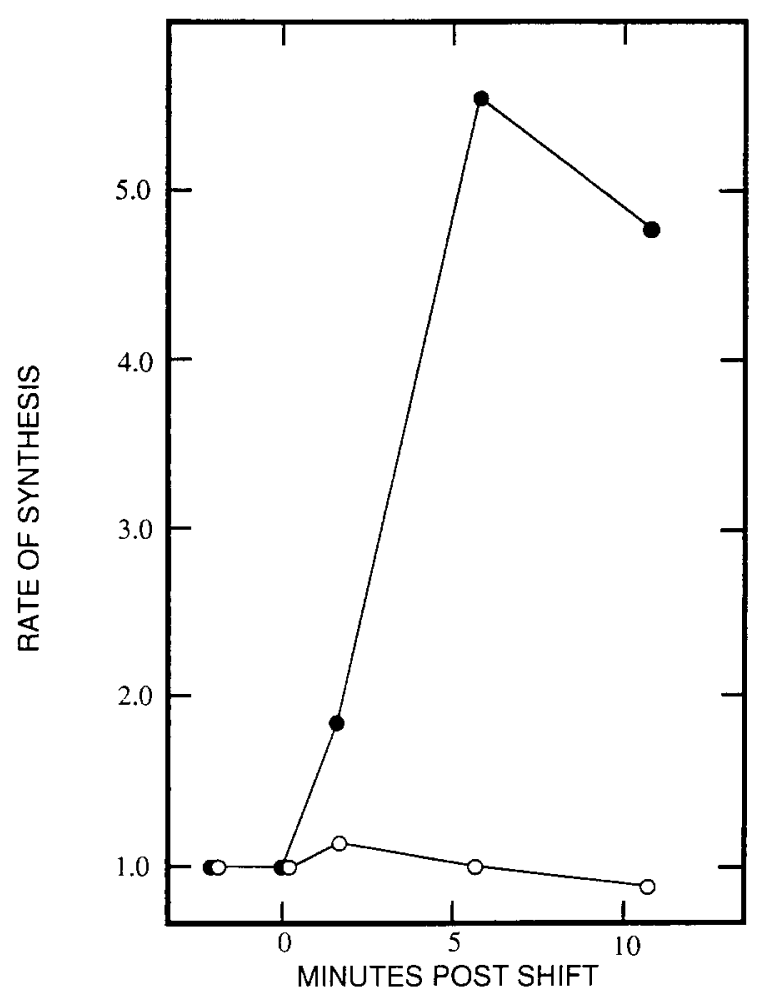

Fig. 3. $\sigma^{32}$ dependence of protein D48.5 synthesis. Strains SC122 (O) and $\mathrm{K} 165(\mathrm{O})$ were grown at $28^{\circ} \mathrm{C}$ in defined rich medium. At an $A_{420}$ of 0.3 , portions of the cultures were labeled with $\left[{ }^{35}\right.$ S]methionine for 5 $\min$ at $28^{\circ} \mathrm{C}$ and for $1 \mathrm{~min}$ at three time points after a shift to $42^{\circ} \mathrm{C}: 0$ $\mathrm{min}, 5 \mathrm{~min}$ post-shift, and $10 \mathrm{~min}$ post-shift. After the labeling period, the cells were chased with thousand-fold excess of cold methionine for 3 $\min$. Extracts were made by sonication and resolved by two-dimensional gel electrophoresis. The spot identified on these gels as being protein D48.5 was removed, processed by using a Packard Sample Oxidizer, and the fractions counted in a Beckman series liquid scintillation counter. The rate of synthesis is expressed relative to the value at $28^{\circ} \mathrm{C}$.

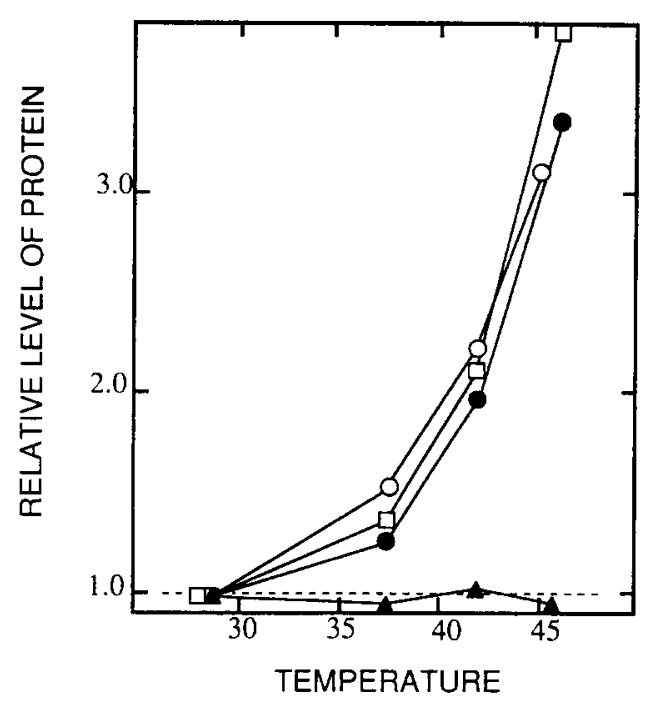

Fig. 4. Relative levels of protein D48.5 and fusion-expressed $\beta$-galactosidase during balanced growth on rich media at different temperatures. To determine the relative level of protein D48.5, cultures of $\left[{ }^{35} \mathrm{~S}\right]$ methionine labeled strain W3110 were grown at $28,37,42$, and $46^{\circ} \mathrm{C}$ to an absorbance $\left(A_{420}\right)$ of 1.0. Extracts were made by sonication and resolved by two-dimensional gel electrophoresis. The spot identified on these gels as being protein D48.5 was removed, processed by using a Packard Sample Oxidizer, and the fractions counted in a Beckman series liquid scintillation counter. The level of protein D48.5 $(\boldsymbol{)})$ at each temperature was normalized to the level at $28^{\circ} \mathrm{C}$. To determine the relative level of $\beta$-galactosidase $(O)$, a reference culture of strain K2357-9 was grown at $28^{\circ} \mathrm{C}$ to an $A_{420}$ of 1.0 . Test cultures were grown at $28,37,42$, and $45^{\circ} \mathrm{C}$. Samples of all cultures were assayed as described in Section 2 . The $\beta$-galactosidase units at the test temperature, divided by the $\beta$-galactosidase units at the reference temperature, is the steady-state level of the enzyme. For reference, the relative levels of the heat shock protein, DnaK $(\square)$ and the non-heat shock protein, Ef-Tu ( $\Delta$ ), were determined using the same methodology as that for protein D48.5.

$46^{\circ} \mathrm{C}$; and this change is similar to that of heat shock proteins DnaK, GroEL, and GrpE $[1,26]$.

\subsection{Protein D48.5 is essential for growth at high tempera- tures}

The fusion strain grew at the same rate as the parent at $37^{\circ} \mathrm{C}$ in rich media, but grew slightly slower than the parent at $42^{\circ} \mathrm{C}$ (data not shown). This suggested that protein D48.5 might be required for normal cellular growth at higher temperatures. To test this hypothesis the parent and fusion strains, K2357 (htpI $\left.{ }^{+}\right)$and K2357-9 ( $h t p I:: l a c Z$ ), were grown in rich glucose MOPS media at $28^{\circ} \mathrm{C}$ and portions of the cultures were shifted to 42 and $46^{\circ} \mathrm{C}$. Growth was monitored by a Zeiss spectrophotometer at $420 \mathrm{~nm}$. The resulting growth curves are shown in Fig. 7.

Upon a shift to $46^{\circ} \mathrm{C}$, the parental strain continued to grow, while the fusion strain ceased to grow shortly after the shift. When the tetracycline sensitive fusion strain derivative K2357-91 was mated with CAG5051 [27], an Hfr strain that complements the map area of $h t p I$ (Peruski 


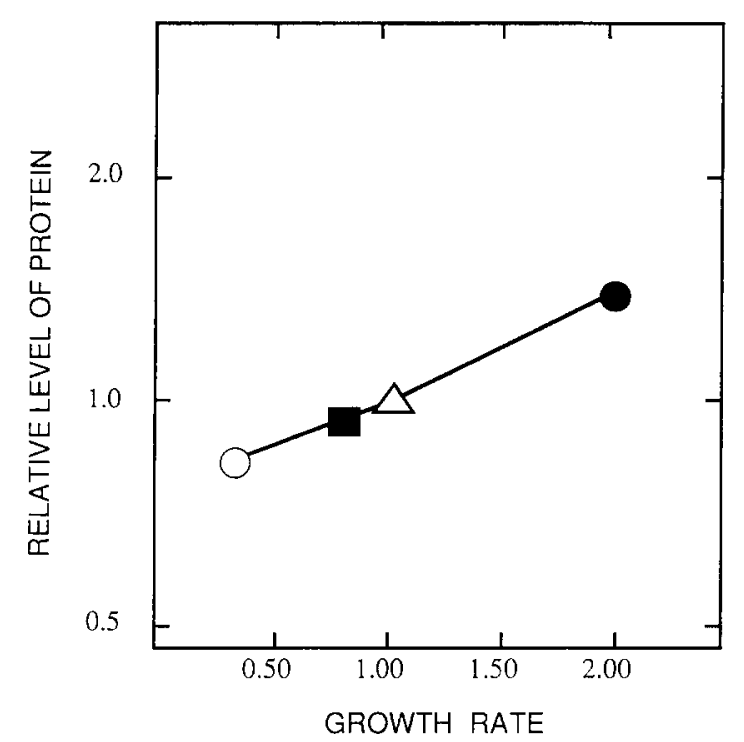

Fig. 5. Effect of medium composition and growth rate on the level of protein D48.5. To determine the regulatory class of protein D48.5, cultures of $\left[{ }^{35} \mathrm{~S}\right]$ methionine labeled strain $\mathrm{W} 3110$ were grown at $37^{\circ} \mathrm{C}$ in acetate minimal $(O)$, glycerol minimal $(\boldsymbol{\square})$, glucose minimal $(\boldsymbol{\Lambda})$, or glucose rich (-) Mops media to an $A_{420}$ of 1.0 . Extracts were made by sonication and resolved by two-dimensional gel electrophoresis. The spot identified on these gels as being protein D48.5 was removed, processed by using a Packard Sample Oxidizer, and the fractions counted in a Beckman series liquid scintillation counter. The level of protein D48.5 present in cells grown in each media was normalized to the level in glucose minimal media.

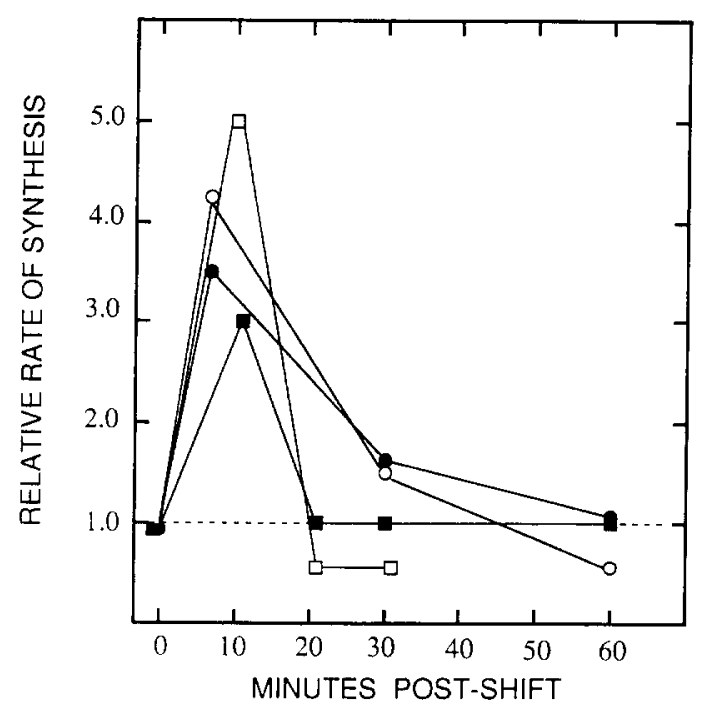

Fig. 6. Relative rates of synthesis of protein D48.5 and fusion-expressed $\beta$-galactosidase after temperature shifts. A steady-state reference culture of strain W3110 labeled with $\left[{ }^{3} \mathrm{H}\right]$ leucine was prepared as described in Section 2. Aliquots of test culture were labeled before temperature shifts and at intervals after shifts with $\left[{ }^{35} \mathrm{~S}\right]$ methionine. Portions of the reference and test cultures were mixed, protein D48.5 resolved by two-dimensional gels and the ${ }^{35} \mathrm{~S} /{ }^{3} \mathrm{H}$ ratio determined. The relative rate of synthesis of protein $\mathrm{D} 48.5$ is its ${ }^{35} \mathrm{~S} /{ }^{3} \mathrm{H}$ ratio, divided by the ratio in the total extract, and normalized to the same ratio of the pre-shift pulse. $\beta$-galactosidase levels of strain $\mathrm{K} 2357-9$ were determined before and after temperature shifts as described in Fig. 4 and relative rates of synthesis calculated as described in Section 2. Protein D48.5: $28 \rightarrow$ $42^{\circ} \mathrm{C}(\Theta)$, and $28 \rightarrow 46^{\circ} \mathrm{C}(\mathrm{O})$. Fusion expressed $\beta$-galactosidase: 28 $\rightarrow 42^{\circ} \mathrm{C}(\square)$, and $28 \rightarrow 46^{\circ} \mathrm{C}(\square)$. and Neidhardt, unpublished results), a recombinant strain, designated K2357-92, was formed. This strain is $h t p I^{+}$as shown by two-dimensional gel analysis (data not shown). In this recombinant, the temperature sensitive growth phenotype is relieved, strongly suggesting that the protein D48.5 gene product is essential for cell growth in rich media at $46^{\circ} \mathrm{C}$ or higher.

\section{Discussion}

This study was made possible by the chance discovery of a previously overlooked heat-inducible protein. Four Mud-Lac fusion strains, constructed in the laboratory of David Friedman at the University of Michigan, proved to be missing the same polypeptide spot out of over 1000 resolved proteins. Our analysis, beginning with one of these fusion strains, has led to the below given five major points about protein D48.5 and a Mud-Lac fusion in its gene.

4.1. A new heat shock protein, designated protein $D 48.5$, and a lacZ fusion in its gene, htpI have been identified

Induction of protein D48.5 and fusion-expressed LacZ are dependent on $\sigma^{32}$. One polypeptide, protein D48.5, was affected by the Mud-Lac insertions. Interestingly, no fusions were found in any of the other heat shock genes and this requires some discussion. Other lac fusions have been made in some of the genes encoding heat shock proteins, for example those of C62.5 and DnaK [11,14]. Failure to find fusions in other heat shock genes could be the result of two factors in the construction of the fusions. First, the fusion population was screened on MacConkey plates at $42^{\circ} \mathrm{C}$, and only moderate sized colonies were selected for further testing. This would eliminate any slow growing fusion strains, such as those that result from insertions into the DnaK gene or the gene for C62.5. Second, colonies that produced moderate amounts of $\beta$ galactosidase as determined by qualitative examination of MacConkey plates incubated overnight were picked from the screened population. As can be seen from the induction ratio of the heat shock proteins, hyperexpression of the genes is transient after a temperature shift. Based on this, if a fusion occurred in a heat shock gene such as $g r p E$, the product of which is almost non-existent under steady-state conditions, the resulting colony phenotype would be at most faint pink and be missed by this screen. Perhaps the only gene fusion that could be detected by this screen is htpI. Its gene product, protein D48.5, is synthesized in moderate amounts under steady-state conditions and loss of the gene is not lethal for the cell at $42^{\circ} \mathrm{C}$; moderate size colonies result from growth on rich plates. 
4.2. The relative level of protein $D 48.5$ in rich media increases across the temperature range from 28 to $46^{\circ} \mathrm{C}$, having a peak level of 3.5 -fold at $46^{\circ} \mathrm{C}$ relative to that at $28^{\circ} \mathrm{C}$

Relative levels of the major heat shock proteins, such as DnaK or GroEL, also increase with temperature [10]. Further evidence that the level of protein D48.5 increases as the growth temperature increases is found in the plot of its differential rate of synthesis following temperature shifts from $28^{\circ} \mathrm{C}$ to either 42 or $46^{\circ} \mathrm{C}$. The differential rate of synthesis of protein $\mathrm{D} 48.5$ and its gene fusion increases at least 3-fold upon shifts from 28 to either 42 or $46^{\circ} \mathrm{C}$. By $20 \mathrm{~min}$ after a shift to $42^{\circ} \mathrm{C}$, the differential rate declines slowly and remains above one. Over the same time-course after a shift to $46^{\circ} \mathrm{C}$, the rate of synthesis rapidly falls below one. The change in the relative rate of synthesis is indicative of the cell undergoing a burst of synthesis that quickly adjusts the level of the protein to that characteristic of the new steady-state temperature.

\subsection{Feedback control of gene expression is operative in the fusion strain}

As for most of the heat shock proteins, the level of protein D48.5 is rapidly increased by a transient burst of syflthesis upon a temperature shift. The very same pattern of synthesis is observed for $\beta$-galactosidase in the fusion strain, indicating that the feed back control for the expression of this gene is operative in the fusion mutant. This finding could mean either that protein D48.5 is not the feedback signal or that an undetected active fragment of protein D48.5 is performing this function in the fusion strain.

4.4. Synthesis of protein D48.5 is nearly constitutive at $37^{\circ} \mathrm{C}$, increasing slightly as the growth rate increases, indicating that it is a class Ic protein

The steady-state level of protein D48.5 in the $E$. coli K12 strain W3110 increases as a function of increasing growth rate, placing it in the Ic group. Protein D48.5 belongs to the same metabolic regulation group in the $E$. coli B/r strain, NC3 (S. Herendeen, R. VanBogelen, and F.C. Neidhardt, unpublished results). Proteins of this group are believed to be involved in transcription, translation, and replication [24]. Those proteins of this group that have been identified include both ribosomal and RNA polymerase subunits, elongation factors, and aminoacyl tRNA synthetases [24].

\subsection{Protein D48.5 is essential for growth in rich media} following a shift from 28 to $46^{\circ} \mathrm{C}$

The parent strain and a Hfr recombinant of the fusion strain survive the shift to the higher temperature, while the
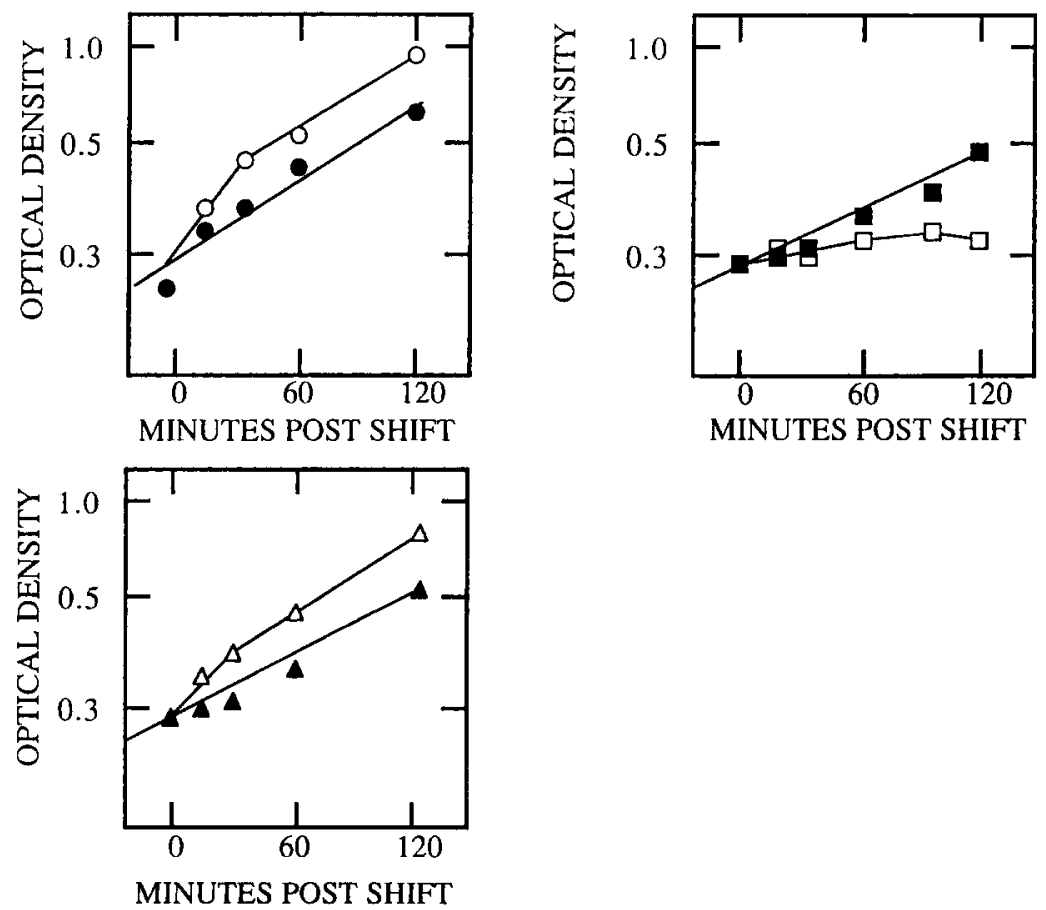

Fig. 7. Protein D48.5 for is essential for growth at high temperatures. Strains were grown in a glucose Mops medium at $28^{\circ} \mathrm{C}$. Portions of the cultures were shifted to $46^{\circ} \mathrm{C}$ at an $A_{420}$ of $\sim 0.3$. Growth was monitored by a Zeiss spectrophometer. Key to panels: (A) K2357 ( $\left.h t p I^{+}\right)$, bacterial growth at $28^{\circ} \mathrm{C}(\mathrm{O})$; bacterial growth after a temperature shift from $28 \rightarrow 46^{\circ} \mathrm{C}(\mathrm{O})$; (B) $\mathrm{K} 2357-9$ ( $h$ tpI: :lacZ), bacterial growth at $28^{\circ} \mathrm{C}(\mathrm{O})$ bacterial growth after a temperature shift from $28 \rightarrow 46^{\circ} \mathrm{C}(\mathrm{O})$; (C) $\mathrm{K} 2357-9 \times \mathrm{CAG} 051\left(\right.$ htp ${ }^{+}$), bacterial growth at $28^{\circ} \mathrm{C}$ ( $\mathrm{C}$ ); bacterial growth after a temperature shift from $28 \rightarrow 46^{\circ} \mathrm{C}(\square)$; (C) K2357-9 $\times$ CAG5051 $\left(h t p I^{+}\right)$, bacterial growth at $28^{\circ} \mathrm{C}(\Delta)$; bacterial growth after a temperature shift from $28 \rightarrow 46^{\circ} \mathrm{C}(\Delta)$. 
growth of the fusion strain quickly ceases. Interestingly, the analysis of heat shock protein C62.5 (GrpE) demonstrated that it, too, is conditionally essential for normal cellular growth at temperatures of $46^{\circ} \mathrm{C}$ or higher [28]. Current evidence indicates that the heat shock response of $E$. coli does not by itself confer thermotolerance [16], so the requirement of these two proteins for normal cellular growth at elevated temperatures remains unknown. Presently, studies are in progress to clone both the $h t p I:: l a c Z$ fusion and the complete structural gene in order to learn more about its regulation and the possible role for protein D48.5 in the cell.

\section{Acknowledgments}

The heat shock fusions were constructed by Alan Schauer and Linda Eades, formerly of this department, and David Friedman. Barbara Bachmann, Carol Gross, Mitch Singer, David Strauss, and William Walter kindly supplied some of the strains and plasmids. Thanks to Ruth VanBogelen, Robert Clark, and Dan Gage for helpful discussion and comments. This work was supported by Public Health Service grant GM17892 from the National Institutes of Health to F.C.N. This work was taken from the doctoral thesis of L.F.P., who was supported by a fellowship from the F.G. Novy Fund.

\section{References}

[1] Lemaux, P.G., Herendeen, S.L., Bloch, P.L., Neidhardt, F.C.. (1978) Cell 13, 427-434.

[2] Neidhardt, F.C. and VanBogelen, R.A. (1987) in Escherichia coli and Salmonella typhimurium: Cellular and Molecular Biology (Neidhardt, F.C., Ingraham, J.L., Low, K.B., Magasanik, B., Schaechter, M. and Umbarger, H.E., eds.), pp. 1334-1345, American Society for Microbiology, Washington, D.C.

[3] Erickson, J.W. and Gross, C.A. (1989) Genes Dev. 3, 1462-1471.

[4] Wang, Q. and Kaguni, J.M. (1989) J. Bacteriol. 171, 4248-4253.
[5] Erickson, J.W., Vaughn, V., Walter, W.A., Neidhardt, F.C. and Gross, C.A. (1987) Genes Dev. 1, 419-432.

[6] Lipinska, B., Sharma, S. and Georgopoulos, C. (1988) Nucleic Acids Res. 16, 10052-10067.

[7] Neidhardt, F.C., VanBogelen, R.A. and Lau, E.T. (1983) J. Bacteriol. 153, 597-603.

[8] Neidhardt, F.C., VanBogelen, R.A. and Vaughn, V. (1984) Annu. Rev. Genet. 18, 295-329.

[9] Bloom, M., Skelly, S., VanBogelen, R.A., Neidhardt, F.C., Brot, N. and Weissbach, H. (1986) J. Bacteriol. 166, 380-384.

[10] Landick, R., Vaughn, V., Lau, E.T., VanBogelen, R.A., Erickson, J.W. and Neidhardt, F.C. (1984) Cell. 38, 175-182.

[11] Goff, S.A. and Goldberg, A.L. (1985) Cell 41, 587-595.

[12] Grossman, A.D., Strauss, D.B., Walter, W.A. and Gross, C.A. (1987) Genes Dev. 1, 525-531.

[13] Taylor, W.E., Strauss, D.B., Grossman, A.D., Burton, Z.F., Gross, C.A. and Burgess, R.R. (1984) Cell 38, 371-381.

[14] Yano, R., Imai, M. and Yura, T. (1987) Mol. Gen. Genet. 207, $24-28$.

[15] Tsuchido, T., VanBogelen, R.A. and Neidhardt, F.C. (1986) Proc. Natl. Acad. Sci. USA 83, 6959-6963.

[16] VanBogelen, R. A., Acton, M.A. and Neidhardt, F.C.. (1987) Genes Dev. 1, 525-531.

[17] Neidhardt, F.C., Bloch, P.L., and Smith, D.F. (1974) J. Bacteriol. $119,736-747$.

[18] Maniatis, T., Fritsch, E.F. and Sambrook, J. (1982) Molecular Cloning: A Laboratory Manual, Cold Spring Harbor Laboratory, Cold Spring Harbor, New York.

[19] Herendeen, S.L., VanBogelen, R.A. and Neidhardt, F.C. (1979) J. Bacteriol. 139, 185-194.

[20] Miller, J.H. (1972) Experiments in Molecular Genetics, Cold Spring Harbor Laboratory, Cold Spring Harbor, New York.

[21] Maloy, R.S. and Nunn, W.D. (1981) J. Bacteriol. 145, 1110-1112.

[22] O'Farrell, P.H. (1975) J. Biol. Chem. 250, 4007-4021.

[23] O'Farrell, P.Z., Goodman, H.M. and O'Farrell, P.H. (1977) Cell 12, $1133-1142$

[24] Pedersen, S., Bloch, P.L., Reeh, S. and Neidhardt, F.C. (1978) Cell $14,179-190$.

[25] Baker, T.A., Howe, M.M. and Gross, C.A. (1983) J. Bacteriol. 156, 970-974.

[26] VanBogelen, R.A., Kelley, P.M. and Neidhardt, F.C.. (1987) J. Bacteriol. 169, 26-32.

[27] Singer, M., Baker, T.A., Schnitz]er, G., Deischel, S.M., Goel, M., Dove, W., Jaacks, K.J., Grossmand, A.D., Erickson, J.W. and Gross, C.A. (1989) Microbiol. Rev. 53, 1-24.

[28] Bardwell, J.C.A. and Craig, E.A.. (1988) J. Bacteriol. 170, 29772983. 